\title{
Comparative treatment scheme between nitrofurantoin and ampicillin in pregnant patients 12 to 16 weeks, gestation with asymptomatic bacteriuria
}

\section{Esquema comparativo de tratamiento entre la nitrofurantoína y ampicilina en pacientes embarazadas de 12 a 16 semanas de gestación con bacteriuria asintomática}

\author{
SARABIA-ALCOCER, Betty†', AKÉ-CANCHÉ, Baldemar, PÉREZ-BALAN, Román and LÓPEZ- \\ GUTIÉRREZ, Tomás
}

Universidad Autónoma de Campeche, Faculty of Medicine, Mexico.

ID $1^{\text {st }}$ Author: Betty, Sarabia-Alcocer / ORC ID: 0000-0002-7912-4377

ID $1^{\text {st }}$ Co-author: Baldemar, Aké-Canché / ORC ID: 0000-0003-2636-5334

ID $2^{\text {nd }}$ Co-author: Román, Pérez-Balan / ORC ID: 0000-0003-2366-6617

ID $3^{\text {rd }}$ Co-author: Tomás, López-Gutiérrez / ORC ID: 0000-0002-3554-1347

DOI: $10.35429 / \mathrm{JOHS} .2021 .25 .8 .1 .5$

Received July 10, 2021; Accepted December 30, 2021

\begin{abstract}
Urinary tract infection is a frequent cause of demand for care in family medicine, it can have a significant participation in maternal and neonatal morbidity. Objective. To compare the treatment scheme 7 with the antibiotic ampicillin in cases of asymptomatic bacteriuria in pregnant women with 12 to 16 weeks of gestation against nitrofurantoin. Material and methods. Observational, cross-sectional, retrospective and analytical study conducted in pregnant patients between weeks 12 and 16 of gestation with asymptomatic bacteriuria. Result. In patients with asymptomatic bacteriuria, a greater persistence of the infection was found when being treated with nitrofurantoin. Pregnant patients with 13 weeks had the highest incidence of asymptomatic bacteriuria with a frequency of $31.82 \%$. Conclusions. Nitrofurantoin may be considered a better treatment option than ampicillin, given its lower incidence rate of asymptomatic bacteriuria in pregnant patients at 12 to 16 weeks' gestation.
\end{abstract}

Bacteriuria, Pregnant women, Treatment scheme

\begin{abstract}
Resumen
La infección de vías urinarias es causa frecuente de demanda de atención en medicina familiar, puede tener una participación significativa en la morbilidad materna y neonatal. Objetivo. Comparar en los casos de bacteriuria asintomática de embarazadas con 12 a 16 semanas de gestación el esquema de tratamiento 7 con el antibiótico contra la nitrofurantoína. Material y métodos. Estudio observacional, transversal, retrospectivo y analítico realizado en pacientes embarazadas entre las semanas 12 a 16 de gestación con bacteriuria asintomática. Resultados. En las pacientes con bacteriuria asintomática se encontró una mayor persistencia de la infección al ser tratadas con ampicilina $63.34 \%$ contra el $36.36 \%$ observado en pacientes tratadas con nitrofurantoína. Las pacientes gestantes con 13 semanas presentaron la mayor incidencia de bacteriuria asintomática con una frecuencia de $31.82 \%$. Conclusiones. La nitrofurantoína puede considerarse mejor opción de tratamiento que la ampicilina, dada su menor tasa de incidencia de bacteriuria asintomática en pacientes embarazadas de 12 a 16 semanas de gestación.
\end{abstract}

Bacteriuria, Mujeres embarazadas, Esquema de tratamiento

Citation: SARABIA-ALCOCER, Betty, AKÉ-CANCHÉ, Baldemar, PÉREZ-BALAN, Román and LÓPEZ-GUTIÉRREZ, Tomás. Comparative treatment scheme between nitrofurantoin and ampicillin in pregnant patients 12 to 16 weeks, gestation with asymptomatic bacteriuria. Journal of Health Sciences. 2021. 8-24:1-5.

$\dagger$ Researcher contributing as First Author 


\section{Introduction}

Pregnancy increases the incidence of symptomatic, particularly acute pyelonephritis (1). Urinary tract infection is one of the most frequent medical complications of pregnancy, second only to anemia and cervicovaginitis (2). Urinary tract infection is a frequent cause of demad for care in family medicine, it is said that it reaches $10 \%$ of all consultations in Mexico (3); The Mexican Institute of Social Security reported asymptomatic bacteriuria in 2 to $10 \%$ of pregnant women, this infection being the most frequent of the urinary tract (2).

The prevalence of asymptomatic bacteriuria $(\mathrm{AB})$ in pregnant women ranges between 4-7 \%, with a range of $2-10 \%$ dependeing on the population studied; generally, originate before pregnancy $(3-5 \%)$ and the percentage of acquired during pregnancy is approximately 1-2 \%. The risk of acquiring BA in the pregnancy increases from $0.8 \%$ in week $12 \mathrm{~m}$ to $1.93 \%$ in the third trimester, reaching its maximum peak between week 9-17 pregnancy $(1,4,5,6)$. Asymptomatic bacteriuria can be defined as bacterial colonization of the urinary tract; detected by a urin culture with a result of $100,000 \mathrm{CFU} / \mathrm{mL}$ of a single bacterium, in the absence of typical symptoms of acute urinary tract infection $(1,7,8)$.

Untreated BA progresses to pyelonephritis in $20 \%$ to $40 \%$ of cases and is associated with premature rupture of membranes, preterm delivery, and product with low birth weight (9). Therefore, it should be done urine culture screening in all pregnant patients for timely diagnosis and treatment of asymptomatic bacteriuria in them $(3,5,10)$.

The main causative agents of bacteriuria are Gram negative bacteria such as Escherichia coli, main uropathogen that causes a large part of cases, as well as other Gram-negative bacteria among which are Proteus mirabilis and Klebsiella pneumoniae and Gram positive as group B streptococci, Staphylococcus saprophyticus and enterococci. Bacteriuria is identified from the first trimester of gestation, reaching BA during pregnancy a prevalence of 4 to $10 \%(11,12,13)$.
Successful treatment of BA reduced the incidence of pyelonephritis by $75 \%$ and decreases the incidence of preterm delivery and risk of low birth weight in the nerwborn $(14,15$, 16). To treat urinary infection various antibiotics have been used, such as: nitrofurantoin, trimethoprim/ sulfamethoxazole, ampicillin, amoxicillin, cefazolin, ceftriaxone, Fosfomycintrometamol, gentamicin, and amikacin; the last two are suggested in case of pyelonephritis (12, $13,17)$.

During pregnancy, plasma concentrations of beta-lactams decrease by about $50 \%$ which can increase resistance levels. Cephalosporins are well tolerated and safe in pregnancy. Nitrofurantoin achieves therapeutic concentrations in urine only and has a level low resistance to uropathogens, its use is safe during pregnancy (17). In vitro sensitivity of the uropathogens to ampicillin and trimethoprimsulfamethoxazole is very low. When compared to the ampicillin, the best sensitivity corresponded to nitrofurantoin (18) The treatment of choice for bacteriuria in pregnancy in the southeast of the country consists of: oral nitrofurantoin, $100 \mathrm{mg}$ dose every 6 hours for 7 days or oral ampicillin, $500 \mathrm{mg}$ every 8 hours for 7 days $(3,8,18,19,20,21)$. Therefore, the purpose of this work is to compare the 7 days treatment scheme with the antibiotic ampicillin against the same scheme using nitrofurantoin, in pregnant patients of 12 to 16 weeks of gestation with asymptomatic bcteriuria.

\section{Methodology}

Study type: Quantitative Study design: observational, cross-sectional, retrospective, and analytical. Universe: Records of pregnant women who attended preanatal care at UMF No. 1. Population: 88 pregnant patients between weeks 12 and 16 of gestation with asymptomatic bacteriuria treated by scheme with the antibiotic ampicillin or nitreofurantoin.

\section{Results}

Of a total of 88 pregnant patients at 12 to 16 weeks' gestation (SDG), they were included in the study 22 patients with a diagnosis of asymptomatic bcteriuria, who were divided into two groups according to the prescribed antibiotic scheme, leaving one group treated with nitrofurantoin and the other with ampicillin. 
Thus, the prevalence of asymptomatic bacteriuria in both study groups, which corresponded to $25 \%$ of the patients who attended prenatal care, higher than that reported in other studies. The average age of both groups of pregnant patients under either of the two treatment was around 26 years. In both groups, the mean gestational age of the patients was around 14 weeks with a mode of 13 weeks (Table 1). The average of consultations corresponded to 2.6 consultations for prenatal control at the time of work.

\begin{tabular}{|c|c|c|}
\hline \multirow[t]{2}{*}{ SDG } & \multicolumn{2}{|c|}{$\begin{array}{c}\text { Asymptomatic Bacteriuria } \\
\text { Cases }\end{array}$} \\
\hline & Frequency & 6 \\
\hline 12 & 3 & 13.64 \\
\hline 13 & 7 & 31.82 \\
\hline 14 & 1 & 4.54 \\
\hline 15 & 6 & 27.27 \\
\hline 16 & 5 & 22.73 \\
\hline
\end{tabular}

Tabla 1 Cases of infections in the study population

In both study groups, once the therapy was completed, the evolution of the infection was determined by performing a urine culture 7 days after the end of the antibiotic treatment, bacteriuria still being found in half of the patients included in the study. By doing the comparison between the treatment schemes, it was found that the group treated with nitrofurantoin had greater therapeutic efficiency than the group with the ampicillin regimen. Thus, of the total number of patients with prescription of nitrofurantoin, in 4 the persistence of bacteriuria was observed (36.36 $\%)$ while 106 with the ampicillin scheme, in 7 pregnant women the infection was not eliminated after treatment $(63.64 \%)$.

Asymptomatic bacteriuria is one of the most studied entities given its frequency and its high relation with complications during pregnancy. In the present study, a prevalency of asymptomatic bacteriuria due to urine culture in a quarter of the patients who attended the control prenatal, higher than that reported in the literature. Although there are studies of this pathology that report that this entity is common in 2 to $8 \%$ of pregnant patients, and especially its association with greater number of pregnancies, based on what was found in the present study, we can infer that the patients are underdiagnosed $(1,2,3,4,7,11,14,18)$.
On of the most likely causes of not to diagnose bacteriuria is that generally only a general urine test is requested in patients pregnant but not the urine culture. This is contrary to what is stipulated in NOM 007SSA2-2016 (20) and in the therapeutic diagnostic guidelines where it is mentioned that urine culture should be requested from the first consultation and routine check-up, especially in weeks 12 to $16(1,2,7,8)$. It was found that in the most frequent gestation week in which bacteriuria appeared asymptomatic was at 13 SDG, with a frequency of $31.82 \%$, which was similar to studies carried out by other authors (2), where it is calculated that the risk of acquiring asymptomatic bacteriuria in pregnancy increases during the $13^{\text {th }}$ week of gestation $(1,4,5,6)$.

Finally, we can conclude that a greater persistence of asymptomatic bacteriuria is observed in the patients treated with ampicillin in relation to those treated with nitrofurantoin, So, we can suggest that nitrofurantoin is a better treatment option of the two analyzed in pregnant patients with 12 to 16 SDG with asymptomatic bacteriuria.

\section{Acknowledgements}

Funded by the researcher's own resources.

\section{Conclusions}

It is advisable to carry out more studies to verify the real prevalence of this pathology since in our médium, urine culture is rarely used (which is the confirmatory test of this pathology), either for little accessible of this resource in the Family Medicine Units, and the low interpretation of the general examination of urine, so it can be deduced that this pathology is underdiagnosed, since the presence of this entity is low and high in our pregnant patients.

It is also important to carry out a complete history and physical examination, as well as adherence to the rules to apply an adequate treatment to our patients, so it is necessary to carry out more local investigations to implement control measures in our patients and avoid possible future complications for both the mother and the infants, since it is necessary to regulate and establish what resources do we have and thus plan them properly, in order to achieve a good use of these, reflecting on the quality of our medical care. 
Similarly, it is necessary for family medicine clinics to have diagnostic methods simple and accesible to all family doctors, to perform confirmatory tests in time and in accordance with the official norms and therapeutic diagnostic guidelines to make the first-class care more efficient level.

Training courses must be implemented institutionally on a regular basis for our family doctors, to provide better care to pregnant patients, since it is a policy of national health, previously established by the Secretary of Health.

\section{References}

1. Abies A, Chauhan S, and Preterm labor (2005). Diagnostic and therapeutic options are nota II alike. The Journal of Family Practice, 54 (3): 245-52.

2. Aungst M, King J, Steele A, Gordon M (2004). Low Colony Counts of Asymptomatic group B Streprococcus Bacteriuria: A survey of practice Patterns, American Journal of perynotology ,21 (7) 403-7.

3. Delzell JE, Lefevre ML (200). Urinary tract infections during preg-urinary tract infections during pregnancy. Am Fam Physician, 61:713-21.

4. SING (2006). Diagnóstico y tratamiento de la infección del tracto bajo durante el embarazo en el primer nivel de atención, Guía práctica clínica IMSS-078-08.

5. COCHRANE (2007) Diagnóstico y tratamiento de la infección del tracto bajo durante el embarazo en el primer nivel de atención, Guía práctica clínica IMSS-07808.

6. Shekelle Arredondo, E. (2006). Diagnóstico y tratamiento de la infección del tracto bajo durante el embarazo en el primer nivel de atención, Guía práctica clínica IMSS-078-08.

7. Shekelle, Hernández. (2007). Diagnóstico y tratamiento de la infección del tracto bajo durante el embarazo en el primer nivel de atención, Guía práctica clínica IMSS-078-08.
8. Echevarria Zarate J, Sarmiento Aguilar E, Osores Plenge F (2006) Infección del tracto urinario y manejo antibiótico. Acta MED Per, 23 (1): 26-31.

9. Fernanda Hernández Blas, Juan Manuel López Carmona, José Raymundo Rodríguez Moctezuma, María Luisa Peralta Pedrero, Román Salvador Rodríguez Gutierrez, Alma Rosa Ortiz Aguirre (2007). Frecuencia de bacteriuria asintomática en embarazadas y sensibilidad antimicrobiana in vitro de los uropatógenos. Ginecol Obstet Mex, 75:325-31.

10. Filippi Fernandez J, Medina N. A (2004). Detección y tratamiento de la bacteriuria asintomática en el embarazo, Rev. Inst. Med. "Sucre”. LXIX, 124: 19-29.

11. Foxman B (2002). Epidemiology of urinary tract infections: incidence, morbidity, and economic cost. Am J Med 2002; 113 (1A): 5S-13S.

12. Hernández Bias F, López Carmona J. Rodríguez Moctezuma J, Peralta Pedrero M, Rodríguez Gutiérrez R. Ortiz Aguirre A (2007). Frecuencia de bacteriuria asintomática en embarazadas y sensibilidad antimicrobiana in vitro de los uro patógenos. Ginecol Obstet Mex, 75:325-31.

13. Macejko Amanda, Schaeffer Anthony (2007). Asymptomatic Bacteriuria and Symptomatic Urinary Tract Infections During Prenancy. Urologiuc Clinics of Noth America, Vol (34).

14. Maldonado Cardenas H, Antolinez Ardila L, Solano Prada M, Tejeiro Rico M, Balbuena Parra A (2005). Prevalencia de bacteriuria asintomática en embarazadas de 12 a 16 semanas de gestación, Med UNAB, 8 (2):78-81.

15. Mignini L, Carroli G, Abalos E. Widmer M, Amigot S, Nardin M, et al (2009). Accuracy of diagnostic test to detect asymptomatic bacteriuria during pregnancy, Obstetrics and Gynecology, 113 (2) 1: 346-51. 
16. Norma Oficial Mexicana NOM-007SSA2-2016 Atención a la mujer durante el embarazo, parto y puerperio y del recién nacido.

17. Pérez Molina J, Gaitan Meza J, Lona Reyes J, Panduro Baron G, Castro Hernández J (2008) Nacimiento pretérmino y bacteriuria asintomática, Ginecol Obstet Mex, 76 (8): 454-60.

18. Quiroga Feuchter G, Robles Torres R, Ruelas Morán A, Gómez Alcala A (2007). Bacteriuria asintomática en mujeres embarazadas. Una amenaza subestimada, Rev. Med Inst. Mex Seguro Soc, 45 (2): 169-72.

19. Serrano Santillan M, Bautista Samperio L, Arrieta Pérez T, Jaimes Valenzuela A (2005). Efectividad del tratamiento corto entre amoxicilina y ampicilina en embarazadas con bacteriuria asintomática. Archivos de Medicina Familiar, 7(3) 7985.

20. Smaill F. Antibiotics for asymptomatic bacteriuria in pregnancy. Cochrance Database Syst Rev 2000; 2: CD000490.

21. Smyth M, Moore J, Glidsmith C (2006). Urinary tract infections: role of the clinical microbiological laboratory. Urologic Nursing, 26: 198-203. 